\title{
Topical Issues in Corporate Governance Development in the Russia's Electric Power Industry
}

\author{
G.I. Sheveleva ${ }^{1 *}$ \\ ${ }^{1}$ Melentiev Energy Systems Institute, Siberian Branch of the Russian Academy of Sciences, Irkutsk, Russia
}

\begin{abstract}
Corporate governance in the Russian power companies is developing slowly, and its importance for increasing their investment appeal remains underestimated. In order to identify the main problems hindering such development, the assessment of corporate practices of these companies was carried out. It was performed mainly as per the criteria of the guidelines of Russia's Bank on compliance with the principles of the Corporate Governance Code, as well as those not included in its guidelines. The results obtained were compared to those of the TopCompetence Corporate Governance Center, the Platforma Center for Social Engineering, the Center for Strategic Studies at the MGIMO University, the Corporate Governance Index of the Independent Directors Association and the HSE University. We benchmarked PJSC LUKOIL that ranks among the world's top 10 companies in terms of the total shareholder return as estimated by the Boston Consulting Group. On the basis of a generalization of all the obtained findings we delineated the topical issues of the development of corporate governance. These issues were mainly concerned with the Boards of Directors and were grouped according to the stages of their nomination, election, current operations and performance evaluation. The emphasis was put on the issues related to the adoption of new managerial technologies.
\end{abstract}

\section{Introduction}

In the course of reforming the Russia's electric power industry in 2003-2008, the main task of attracting investments remained unsolved. A non-market driven procedure of capacity contracting (CC) was adopted for financing, as a result of which the reformed power generating companies were indemnified for their investment in new capacity additions. After the expiration of the CCs, another large-scale upgrading program for combined heat and power plants was enacted again. The projects deemed eligible for the program will also be entitled to guaranteed break-even arrangements by imposing higher capacity tariffs on the consumer [1]. The investment appeal of Russian power companies (hereinafter "power companies") remained at a relatively low level. Its improvement depends on the quality of corporate governance, which is considered one of the determining factors in international practices [2].

The main indicator of the quality of corporate governance is the compliance of companies with the Corporate Governance Code (hereinafter Code), developed on the basis of international standards [3]. This has resulted in allocating a high priority to assessment of compliance of corporate governance in power companies with the guidelines of Russia's Bank (hereinafter Bank) on compliance with the Code and the identified criteria of the Code, which were not included in its guidelines.

We performed a comparative analysis of the obtained findings against the evaluation data by analytical centers, for the purposes that included obtaining further information on the quality of corporate governance as based on online surveys of investors [4-8].

PJSC LUKOIL's benchmarking was carried out, mainly to identify corporate governance problems faced by power companies when adopting new technologies.

We studied the 12 public joint-stock companies of the electric power industry that published Annexes "On Compliance with the Principles and Guidelines of the Corporate Governance Code" in their annual reports for the year 2017 (Inter RAO, Enel Russia, RusHydro, OGK-2, Unipro, TGK-1, TGK-2, Mosenergo, Quadra, T Plus, TGK-14, Irkutskenergo) [9-20]. We made use of additional data: those coming from official corporate websites; the Bank's guidelines on compliance with the Code [21]; the author's published research on the subject [22]; the New Economic School [23]; the Russian Institute of Directors [24]; and the Boston Consulting Group total shareholder return rating for the year 2019 [25].

Unlike with the widespread approach that deals only with the largest power companies and thus precludes us from getting an overall view of the quality of corporate governance in the Russia's power industry, we studied virtually all of them.

The results of the study are applicable to improving the efficiency of corporate governance in power companies and to making more informed and balanced investment decisions by investors.

\section{Corporate governance practices}

* Corresponding author: sheveleva@isem.irk.ru 
The current practices of corporate governance in power companies are identified by the following assessment methods:

- Compliance with the Bank's guidelines on compliance with the Code (a conventional and an in-depth methods),

- Compliance with the Code criteria not included in the Bank's guidelines,

- Compliance with the findings of the analytical centers,

- PJSC LUKOIL's benchmarking.

\subsection{Compliance with the Bank's guidelines on adhering to the Code}

The assessment of compliance of corporate governance with the Bank's guidelines on compliance with the Code in power companies was mainly based on the data provided by the companies themselves in Annexes "On Compliance with the Principles and Guidelines of the Code of Corporate Governance" in their annual reports for the year 2017. The assessment was performed by a conventional and an in-depth method.

\subsubsection{Conventional method}

The conventional method is typical of most companies and assesses their compliance with the 79 Level 2 principles of corporate governance of the Code that have three-digit codes assigned to them (for example, "1.1.1." or "1.2.3.", etc.). The status of compliance with these principles ("compliant", "partially compliant", "noncompliant"), when relying on this method, was treated without a further breakdown by the compliance criteria for each of them.

The conventional method of assessment revealed the presence of leading and outsider companies with respect to their compliance with corporate governance principles. Of the 79 principles reviewed, the leading companies (PJSC Inter RAO, PJSC Enel Russia and PJSC RusHydro) complied with the 73, 62 and 59 principles, respectively. PJSC Quadra and PJSC TGC-2 that are the outsider companies that ranked at the bottom of the list complied with 33 and 32 principles respectively. PJSC Inter RAO, PJSC Enel Russia, and PJSC RusHydro proved partially-compliant with 4, 13, and 17 principles, respectively. The corresponding values for PJSC Quadra and PJSC TGK-2 are 27 and 32 principles respectively, thus lagging behind PJSC Inter RAO and scoring 7 to 8 times lower. The disparity between the companies that performed best and worst with respect to the number of principles they failed to comply with was even more pronounced. In particular, the number of principles PJSC Quadra does not comply with exceeds that of PJSC Inter RAO by a factor of 9.6.

These results are more evident when it comes to the share of each compliance status ("compliant", "partially compliant", "non-compliant") in the total of 79 assessed principles: PJSC Inter RAO - 92\%, 5.5\%, 2.5\%; PJSC Enel Russia - 75\%, 22\%, 3\%; PJSC RusHydro - 74.7\%, $21.5 \%, 3.8 \%$. Outsider companies: PJSC Quadra $41.8 \%, 34.2 \%, 24.0 \%$, PJSC TGC-2 - 40.5\%, 40.5\%, $19.0 \%$. Outsider companies saw a clear increase in the number of principles they "partially comply with" and "do not comply with" to that of the leading companies.

\subsubsection{In-depth method}

The in-depth method of assessment allowed for a more unbiased view of corporate governance practices in the companies we studied. All 128 criteria for compliance with Level 2 principles of the Code recommended by the Bank were taken into account here. The leading companies identified earlier had the following values of the compliance status with respect to these criteria: PJSC Inter RAO - 91\%, 6\%, 3\%, PJSC Enel Russia - 81\%, $13 \%, 6 \%$, and PJSC RusHydro - 78\%, 20\%, 2\%. The shares of compliance status values have been redistributed, mainly towards an increase in the number of the criteria that were not complied with. This was more typical of the outsider companies: PJSC Quadra $51 \%, 22 \%, 27 \%$ and PJSC TGC-2 - 47\%, 31\%, 23\%. However, this method of assessment significantly reduced their lagging behind PJSC Inter RAO in terms of all compliance status values. Moreover, we identified PJSC TGC-1 as having the compliance status values comparable to those of the leading companies, that is $80 \%, 18 \%$, and $2 \%$, respectively.

We would like to reiterate that the assessment was made on the basis of the data provided by the power companies in their reports "On Compliance with the Principles and Guidelines of the Corporate Governance Code". A thorough analysis of their reliability was not carried out. However, the study revealed unreliable data, which increased the number of the criteria that power companies failed to comply with. In particular, all power companies claimed their compliance with Level 2 principle 5.1.3 that states that "A company has the anticorruption policy in place". However, only two of them (PJSC Inter RAO and PJSC RusHydro) actually developed, approved, and presented the Fraud and Corruption Prevention Policy in their internal documents.

\subsection{Compliance with the Code criteria not included in the Bank's guidelines}

Criteria not included in the Bank's guidelines were identified by comparing the guidelines of the Code [3] against those of the Bank [21]. Their compliance was assessed on the basis of the information coming from official websites of power companies. Based on the results of the assessment of compliance with the identified criteria of the Code that were not included in the criteria recommended by the Bank, the number of criteria the power companies fail to comply with increased by $6-10 \%$.

Of all the criteria of the Code that were identified as those not complied with, we highlighted the criteria that the overwhelming majority of power companies failed to meet. They were grouped according to the principles of the Code. More than half of them were directly related to violations of the principles that deals with the Board of Directors. The other criteria that were not met were 
related to the principles of remuneration systems, material corporate actions, information disclosure, and shareholder rights. All these criteria were indirectly related to the Boards of Directors, as they belonged to their area of responsibility within the scope of delegated authority.

\subsection{Alignment with the findings of analytical centers}

The obtained findings were compared to the relevant data of the TopCompetence Center and the Corporate Governance Index of the Independent Directors Association and the HSE University based on the criteria of the British Good Governance Index and turned out to be comparable with respect to the assessment criteria. However, taking into account the data of analytical centers based on online surveys of stakeholders, none of the power companies made it to the top $10[6,8]$. It turned out that these companies were not competitive scoring low on the factors that are deemed crucial for investors that is the Board of Directors, market capitalization, transparency and consistency of the dividend policy.

Based on the Q4 Quarterly Reports for the year 2018, only the leading companies we identified enjoyed average market capitalization (more than 2 billion US dollars): PJSC Inter RAO - 5846.7 million US dollars, PJSC RusHydro - 2977.9 million US dollars. The rest of the power companies (except PJSC Unipro) had low market capitalization. In particular, the outsider companies were valued as follows: PJSC Quadra - 80.8 million US dollars, PJSC TGK-2 - 49.0 million US dollars. Internationally, companies with low market capitalization generally have bad reputations and are risky. In most cases, they are considered to be fraudulent, involved in uncontrolled cash withdrawals to foreign offshore zones, including non-transparent transactions with offshore partners that are oftentimes affiliated with their key shareholders.

The findings of the study of dividend history data of power companies in 2013-2018 showed a relatively low return on their shares, lack of transparency, and an inconsistent dividend policy.

\subsection{PJSC LUKOIL's benchmarking}

The Russian energy company PJSC LUKOIL was chosen for benchmarking due to the high total shareholder return in the Boston Consulting Group rating published in 2019. Benchmarking was carried out mainly with respect to the adoption of new managerial technologies in the corporate practice, including the use of telecommunication means at the stages of nomination, election, current activities, and performance evaluation of the Boards of Directors. The benchmarking data were taken into account when formulating the problems of corporate governance development faced by power companies.

\section{Problems of corporate governance development}

On the basis of the generalized data of the performed assessment of corporate governance in power companies we arrived at the topical issues inherent in its development that were mainly related to the Boards of Directors. A strong Board of Directors as it stands in modern corporate practice is the key management body and the main instrument to ensure the leadership of companies in the field of corporate governance. Its role is becoming truly strategic in the face of the new challenges of changing the general paradigm of corporate governance and the development of digital technologies.

The main problems of corporate governance development were grouped according to the "life cycle" stages of the Boards of Directors:

- Nomination.

- Election.

- Current activities.

- Performance evaluation.

\subsection{Nomination}

- Absence of a list of persons entitled to participate in the General Meeting of Shareholders (GMS) that enables shareholders to do the following: evaluate the balance of power at the upcoming meeting; jointly nominate candidates to the Board of Directors; discuss and agree on possible voting options; and appoint their representative to participate in the GMS.

- Non-transparent procedure for nomination of candidates to the Board of Directors.

- Absence of comprehensive information on the candidates to the Board of Directors approved for voting, which is necessary to get an idea of their personal and professional qualities (information on who nominated them, whether they are free of conflicts of interest, as well as the information on their relations with affiliated persons and major counterparties of the Company, compliance with independence criteria, and other information that may affect the performance of their duties).

- Absence of an online bulletin board for preliminary discussion by shareholders of candidates to the Board of Directors, which would allow taking into account the diversity of opinions of shareholders and ensuring that the Board's composition complies with the requirements of the law, the objectives of the company, and its corporate values. The special importance of such a procedure lies in the discussion of the ethical and behavioral qualities of potential candidates, their ability to work as a team and to make concessions, as well as the identification of advocates of "support groups", bystanders, conventionalists, and "constant" critics who are undesirable as the Board of Directors members.

\subsection{Election}

- Absence of telecommunication facilities that would ensure remote access of shareholders to participate in the GMS (GMS broadcasting on the Company's website, adoption of video-conferencing). 
- Absence of an electronic voting system that would enable filling in the ballot through a personal account on the company's website and ensuring adequate reliability, security, and authentication of persons participating in the GMS.

\subsection{Current activities}

- Absence of appropriate Committees of the Board of Directors and (or) their poor performance, which compromises the quality of important decisions made at the meetings of the Board of Directors and efficiency of their consideration without proper preparation by these Committees.

- Absence of the team-spirit in the activities of the Board of Directors members when making decisions without comprehensive discussions of the issues under consideration and not being informed by different opinions.

- Meetings tend to be held by correspondence with no telecommunication facilities for the participation of members of the Board of Directors in the discussion of important issues by means of remote access.

- Low competence of members of the Board of Directors in the field of innovation, information, and digital technologies.

- Inadequacy of individual critical decisions and the culture of the decision-making process.

- Lack of monitoring of the implementation of decisions taken.

- Failure to update the composition and content of the body internal corporate documents to meet changed conditions and new challenges of our time.

- Lack of an actual anti-corruption policy and efficient models of interaction with persons interested in reporting such violations. The inefficiency of a traditional confidential communication channel for such complainants available on websites of some of the companies as it generally boils down to an email address or phone number details.

\subsection{Performance evaluation}

- Lack of a formalized procedure for performance evaluation of the Board of Directors, analytical tools, and the use of the retrieved data.

- Absence of the Regulation "On Performance Evaluation of the Board of Directors" developed and approved in the internal documents of the companies, including its justification; procedure and tools; and the format of public disclosure.

- Non-transparency of the amount and determination of annual remuneration for the members of the Board of Directors.

- Substantial amounts of this remuneration without objective grounds.

- Absence of correlation between the amount of annual remuneration of the Board of Directors members and the performance of power companies, which does not contribute to the convergence of their financial interests and those of shareholders.

\section{Conclusion}

In order to enhance the investment appeal of power companies, it is necessary to handle the issues of the quality of corporate governance. For the purpose of identifying such problems, an assessment of their current corporate practices was performed. It stood out from commonly used assessment methods in two ways. First of all, it was the coverage of virtually all companies active in the electric power industry, not just the biggest ones. Secondly, it was the application of all 128 criteria of compliance with the Level 2 principles of the Code recommended by the Bank along with those not included in its guidelines.

A significant number of criteria were identified that were power companies failed to comply with. We delineated the topical issues of corporate governance development based on the criteria related to the Boards of Directors that the overwhelming majority of power companies fail to comply with. The issues were grouped according to the stages of the Boards nomination, election, current activities, and performance evaluation. These issues were clarified and supplemented by the results of their comparison with the data published by analytical centers and the PJSC LUKOIL's benchmarking, mainly in the context of the adoption of new managerial technologies.

It is possible that the identified problems of corporate governance development in electric power companies will be mitigated in the future, in particular, by assessing the criteria for compliance with the G20/OECD corporate governance principles that were not included in the Russian Code.

\section{References}

1. The RF Government approves 1.9 trillion ruble spending on the programme of combined heat and power plants upgrading. [Online]. Available: http://www.bigpowernews.ru/print/86618.phtml

2. OECD. Principles of corporate governance. G20/OECD Publishing, Paris (2016). [Online]. Available: http://dx.doi.org/10.1787/9789264252035-ru

3. Corporate Governance Code. Regulations and up-todate information of the Central Bank of the Russian Federation, Vestnik Banka Rossii, 40 (2014)

4. Transparency in corporate reporting: A report by Transparency International - Russia (2018). [Online]. Available: https://transparency.org.ru/special/trac2018russia/

5. National Corporate Governance Index (2018). [Online]. Available: http://www.topcompetence.ru/Images/Uploads/Publi cations/National-CG-Index-2018-

TopCompetence.pdf 
6. Corporate Governance in Russia: Genre identity crisis and hopes for the future ("Platforma" Center for Social Engineering, Moscow, 2018). [Online]. Available: http://www.nand.ru/upload/medialibrary/news

7. Zavyalova E.B., Kondratiev V.B., Corporate governance as a contributing factor to enhancing the investment appeal (MGIMO University, Moscow, 2014)

8. Corporate Governance Index of Russia (2017). [Online]. Available: http://nand.ru/upload/ux/corporate_governance_inde x_2017.pdf

9. Report on compliance of JSC TGK-2 with the principles and recommendations of the Corporate Governance Code. [Online]. Available: http://www.tgc-

2.ru/upload/iblock/f8d/areport_2016.pdf

10. Report on compliance of PJSC Quadra with the principles and recommendations of the Code of Corporate Governance recommended by the Bank of Russia. [Online]. Available: https://www.quadra.ru/wpcontent/uploads/2018/06/gosa2018_AnnualReport.p df

11. Report on the compliance of PJSC TGC-1 with the principles and recommendations of the Corporate Governance Code. [Online]. Available: http://www.tgc1.ru/fileadmin/ir/reports/annual/2017/ godovoi_otchet_tgk-1_2017.pdf

12. Information on compliance of PJSC Enel Russia with the principles and recommendations of the Corporate Governance Code. [Online]. Available: https://www.enelrussia.ru/content/dam/enel$\mathrm{ru} /$ documents/ru/investors/annual/Enel_Annual_rep ort-2017-rus.pdf

13. Report on compliance of PJSC Unipro with the principles and recommendations of the Corporate Governance Code. [Online]. Available: http://www.unipro.energy/shareholders/disclosure/a nnual_reports/

14. Report on compliance of PJSC OGK-2 with the principles and recommendations of the Corporate Governance Code. [Online]. Available: https://www.ogk2.ru/rus/si/infodisclosure/year/

15. Report on compliance of PJSC TPlus with the principles and recommendations of the Corporate Governance Code. [Online]. Available: http://www.tplusgroup.ru/fileadmin/f/voltgc/ir/discl osure/documents/GO/T_Pljus_PAO_GO_2016.pdf

16. Report on compliance of PJSC Mosenergo with the principles and recommendations of the Corporate Governance Code. [Online]. Available: http://www.mosenergo.ru/d/textpage/ad/173/godovo j-otchet-17.pdf

17. Report on compliance of PJSC TGC-14 with the principles and recommendations of the Corporate Governance Code. [Online]. Available: https://www.tgk- 1.com/upload/medialibrary/876/go_2017_dlya_sayt a_itog.pdf

18. Report on compliance with the principles and recommendations of the Corporate Governance Code. [Online]. Available: http://www.interrao.ru/upload/doc/Inter_RAO_AR2 017 ru_web.pdf

19. Report on compliance with the principles and recommendations of the Corporate Governance Code. [Online]. Available: http://www.rushydro.ru/upload/iblock/90d/KnigaPrilozhenij-2017-rus.pdf

20. Report on compliance of PJSC Irkutskenergo with the principles and recommendations of the Corporate Governance Code. [Online]. Available: http://www.irkutskenergo.ru/gi/31500

21. Bank of Russia Information Letter No. IN-06-52/8 dated February 17, 2016 [Online]. Available: https:/www.garant.ru/products/ipo/prime/doc/71237 796/

22. G.I. Sheveleva, Areas for the improvement in corporate governance in the Russian electric power industry, Proceedings of 2017 Tenth International Conference "MLSD", Moscow, 1-4 Oct., IEEE, DOI: 10.1109/MLSD.2017.8109686

23. Guriyev S.M., Myths of economics. Fallacies and stereotypes disseminated by mass media and politicians (Mann, Ivanov, and Ferber, Moscow, 2017)

24. I.V. Belikov, Aktsionernoye obshchestvo: voprosy korporativnogo upravleniia 4, 14 (2008)

25. Value Creators Rankings (2018). [Online]. Available: https://www.bcg.com/ruru/publications/2018/interactive-value-creatorsrankings-20th-anniversary-edition.aspx 